\title{
Description of the 3rd instar larvae of the genus Scatophaga Meigen (Diptera: Scatophagidae) from Hokkaido*
}

\author{
Hitoshi SASAKI** \\ ** Laboratory of Entomology, The College of Dairying and The Junior \\ College of Dairying, Ebetsu, Hokkaido 069-01, Japan
}

(Received : July 28, 1980)

\begin{abstract}
In this paper, the author described and redescribed the 3 rd instar larvae of 3 species belonging to the genus Scatophaga Meigen, namely S. scybalaria (Linné), S. stercoraria (Linné) and $S$. suilla (Fabricius), and presented a key to the species from Hokkaido.
\end{abstract}

\section{INTRODUCTION}

Fly larvae of the genus Scatophaga are known to be scavenger and many of them occur in animal dung. Hitherto 3 species of adults were recorded from Hokkaido (Fukuhara and Kurahashi, 1966 a, b). Therefore, our knowledge of their larvae are still fragmentary.

On the larvae of $S$. stercoraria, Cotterell (1920) and Schumann (1959/60) described in detail. The larvae of the other 2 species, $S$. scybalaria and $S$. suilla have so far been unknown and they are described and figured here for the first time.

\section{Methods of Collecting LaRvaE}

Adult flies mating were collected by sweeping net in the pasture and identified. A pair of flies were kept in each plastic cup, $6 \mathrm{~cm}$ in height $\times 12 \mathrm{~cm}$ in diameter, with fresh cow dung for oviposition. The eggs laid in the dung were transferred into the other cups with fresh cow dung and they were reared to mature larvae. About a half of the mature larvae was killed in boiling

* This study was partly reported at 30 th meeting of the Japan Society of Sanitary Zoology.

** 佐々木均: 酪農学園大学・短期大学害虫学教室 （厂069-01 北海道江別市西野幌 582） water and preserved in $70 \%$ ethanol. The remaining larvae were reared to adults in order to reconfirm the species. Body length was measured in the extended state. Cephalopharyngeal sclerites and posterior spiracles were mounted in Canadian balsam and were illustrated under an optical microscope.

The preserved larvae were refixed with glutaraldehyde and osmic acid, and then dehydrated through a graded ethanol. Specimens were then dried by the conventional critical point method. The dried specimens were mounted on specimen stubs, spattercoated with gold and examined with a scanning electron microscope (HHS-2R).

\section{KEY TO THE SPECIES OF 3 RD INSTAR LARVAE OF SCATOPHAGA FROM} HOKKAIDO

1. Fifth to 12 th segments covered with numerous spines S. stercoraria

- Fifth to 11 th segments only with spinebands around anterior margin and spots of ventral spines.......................... 2

2. Fifth to 9 th segments with ventral spines; small species, body length about $7-8 \mathrm{~mm}$ S. suilla

- Fifth segment without ventral spines; large species, body length about 11-12 mm S. scybalaria 

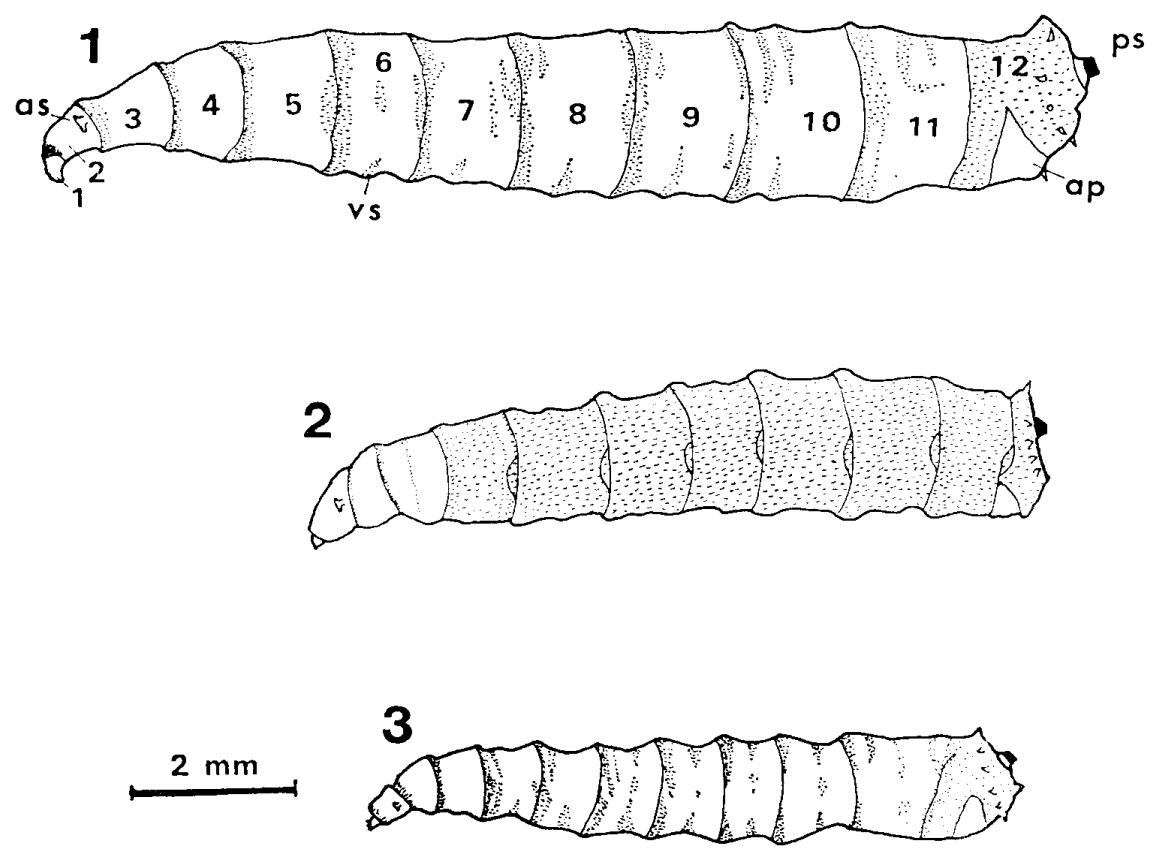

Figs. 1-3 Lateral view of 3rd instar larvae

Fig. 1 S. scybalaria Fig. 2 S. stercoraria Fig. 3 S. suilla
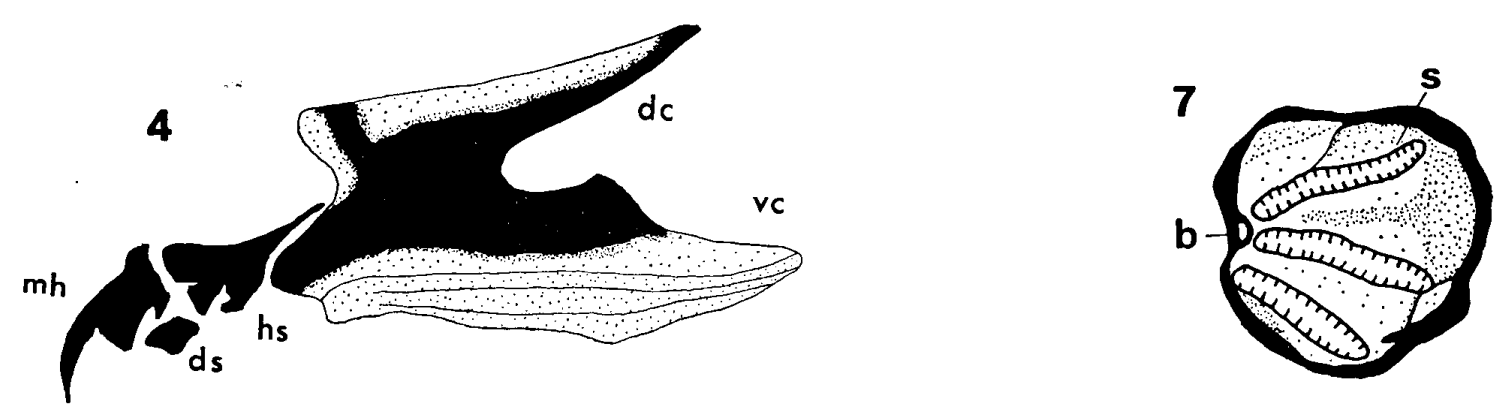

8
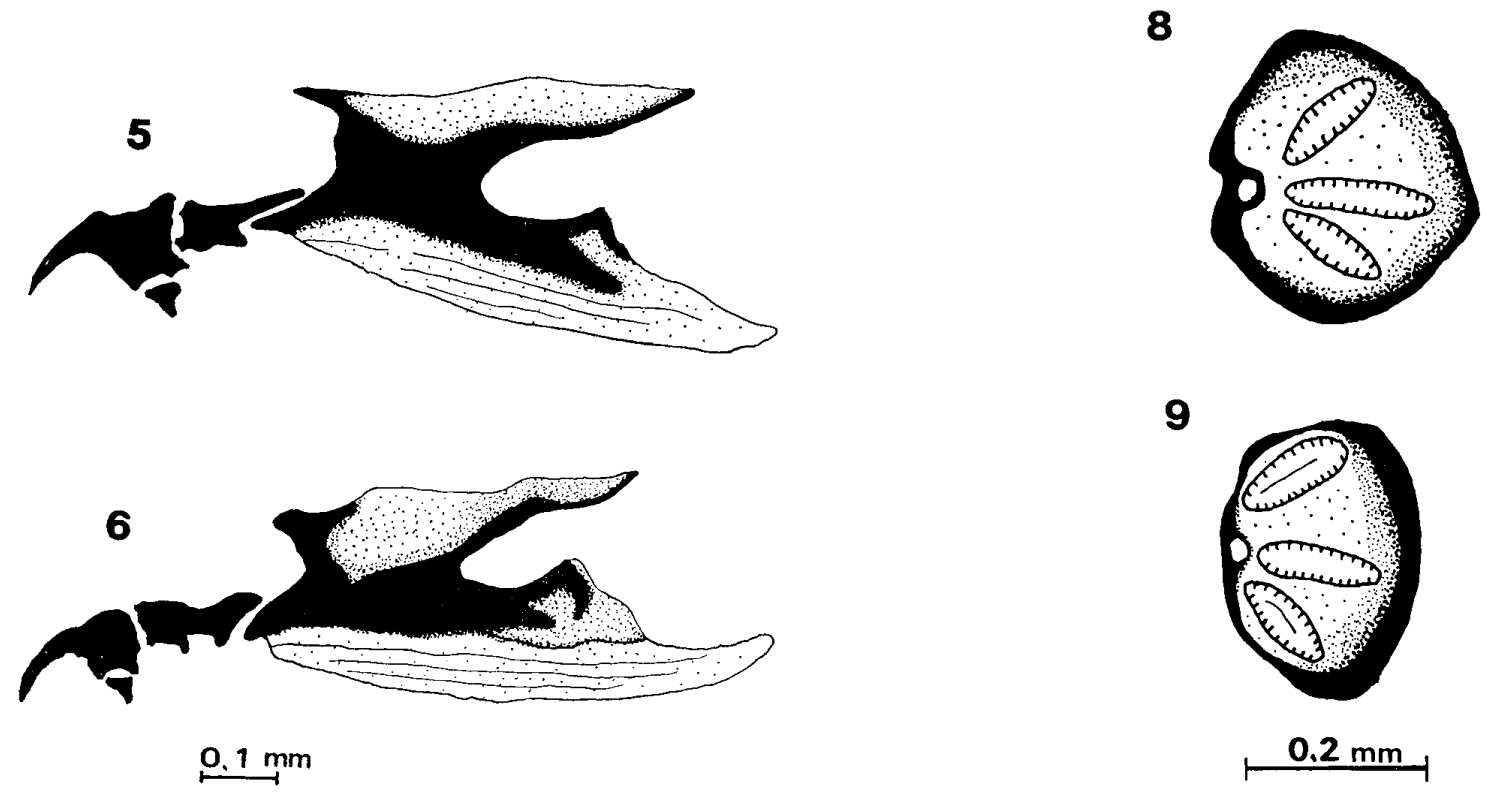

$0.1 \mathrm{~mm}$

Figs. 4-6 Cephalopharyngeal sclerites

Fig. 4 S. scybalaria Fig. 5 S. stercoraria Fig. 6 S. suilla

Figs. 7-9 Posterior spiracle

Fig. 7 S. scybalaria Fig. 8 S. stercoraria Fig. 9 S. suilla 

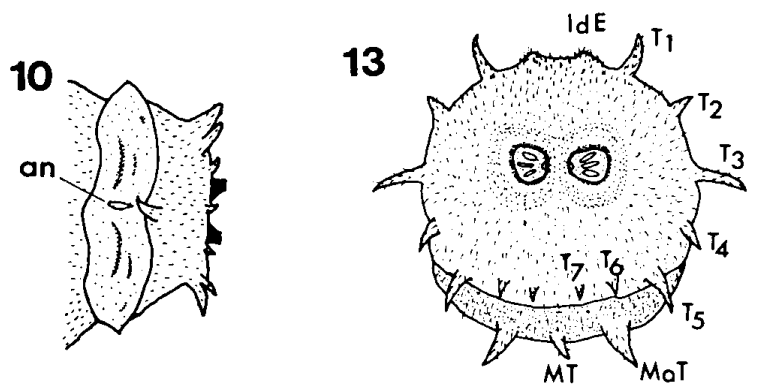

11

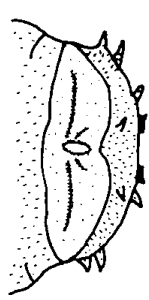

14

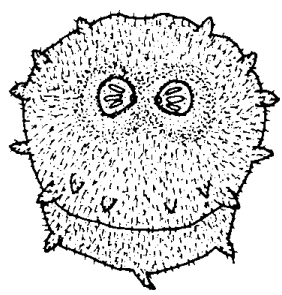

12

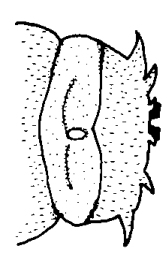

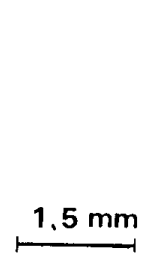

15

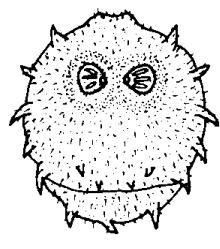

Figs. 10-12 Ventral view of 12 th segment

Fig. 10 S. scybalaria Fig. 11 S. stercoraria Fig. 12 S. suilla

Figs. 13-15 Posterior view of 12 th segment

Fig. 13 S. scybalaria Fig. 14 S. stercoraria Fig. 15 S. suilla

AbBreviations Used

IN FIGURES

$\begin{array}{ll}\text { an } & \text { anus } \\ \text { ap } & \text { anal plate } \\ \text { as } & \text { anterior spiracle } \\ \text { b } & \text { button } \\ \text { dc } & \text { dorsal cornua } \\ \text { ds } & \text { dental sclerite } \\ \text { hs } & \text { hypostomal sclerite } \\ \text { IdE } & \text { Inner dorsal Elevation } \\ \text { MaT } & \text { Mesalanal tubercle } \\ \text { mh } & \text { mouth hook } \\ \text { MT } & \text { Mesal tubercle } \\ \text { ps } & \text { posterior spiracle } \\ \text { T1 } & \text { Tubercle-1 } \\ & \\ \text { T7 } & \text { Tubercle-7 } \\ \text { s } & \text { slit } \\ \text { vc } & \text { ventral cornua } \\ \text { vs } & \text { ventral spines } \\ \text { 1-12 } & \text { Body segment }\end{array}$

\section{DESCRIPTION}

\section{Scatophaga scybalaria (Linné, 1761)}

(Figs. 1, 4, 7, 10, 13, 16, 19)

Japanese name: Kibane Fun-bae

Musca scybalaria Linné 1761, Fauna Suecica, p. 1,860

Scatomyza scybalaria Fallén 1819, Dipt. Suec. Scatomyz. p. 3

Scopeuma scybalarium Meigen 1826, System. Beschr., Bd. 5, S. 247

Scatophaga scybalaria Macquart 1835, S. à Buff., Vol. 2, p. 392

Body : length about $11-12 \mathrm{~mm}$, cylindrical and tapering anteriorly and truncated posteriorly, creamy white; 2 nd to 12 th segments with spine-band on anterior margins; 6 th to 10 th segments with ventral spines; the last segment with 7 pairs of tubercles, a pair of mesalanal tubercles and mesal tubercle, a pair of inner dorsal elevations evident.

Anterior spiracles: with 16-17 branches.

Posterior spiracles: wry rounded shaped and brownish ; button present ; interspiraclar processes all dendriform.

Cephalopharyngeal sclerites: dark brown and extremely horn shaped mouth hook; accessory sclerites absent; dental sclerite wry diamond shaped.

Material examined: 13 examples, Nopporo, Hokkaido, X 3, 1977.

Bionomics: This species is abundant and distributed widely in pastures of Hokkaido. The adults seem to like a shady place such as pasture with high plants and shades of urine patches.

The larvae are mainly found in dung on such shady places.

\section{Scatophaga stercoraria (Linné, 1763)}

(Figs. 2, 5, 8, 11, 14, 17, 20)

Japanese name: Hime Fun-bae

Musca stercoraria Linné 1763, Fauna Suecica, p. 1,861

Scatomyza stercoraria Fallén 1819, Dipt. Suec. Scatomyz., p. 4

Scopeuma stercorarium Meigen 1826, System. Beschr., Bd. 5, S. 248

Scatophaga stercoraria Macquart 1835, S. à Buff., Vol. 2, p. 393

Description of $3 \mathrm{rd}$ instar larvae : 
Cotterell, G. S. 1920, Proc. Zool. Soc. London, 1920 : 629-647

Sack, P. 1937, 62a Cordyluridae, S. 6, Textfig. 11

Schumann, H. 1959/60, Wissenschaftliche Zeitschrift der Ernst-Moritz-Arndt-Universität Greifswald, Mathematisch-naturwissenschaftlich Reihe, Nr. 3/4: 209-215

Body: length about $9-10 \mathrm{~mm}$, cylindrical and tapering anteriorly and truncated posteriorly, creamy white; 5 th to 12 th segments heavily covered with numerous spines; $3 \mathrm{rd}$ segment with spine-band on anterior margin; 4 th segment with spine-bands on anterior margin and middle of segment; the last segment with 7 pairs of tubercles, a pair of mesalanal tubercles and a mesal tubercle, a pair of inner dorsal elevations not evident.
Anterior spiracles: with 13-21 branches.

Posterior spiracles: rounded shaped and brownish; button present; peritreme near button hollowly; interspiraclar process existing between middle and lower slits maniform and the others dendriform.

Cephalopharyngeal sclerite: horn shaped and slender mouth hook; accessory sclerite absent; dental sclerite trianglar shaped.

Material examined : 16 examples, Nopporo, Hokkaido, IX 12, 1977.

Bionomics: This species is commonly found in Japan. The males are found on dung in a sunny place such as pastures with low plants and paddocks. The females are usually observed on the grasses of pastures.

The larvae are mainly found in dung on such sunny places.
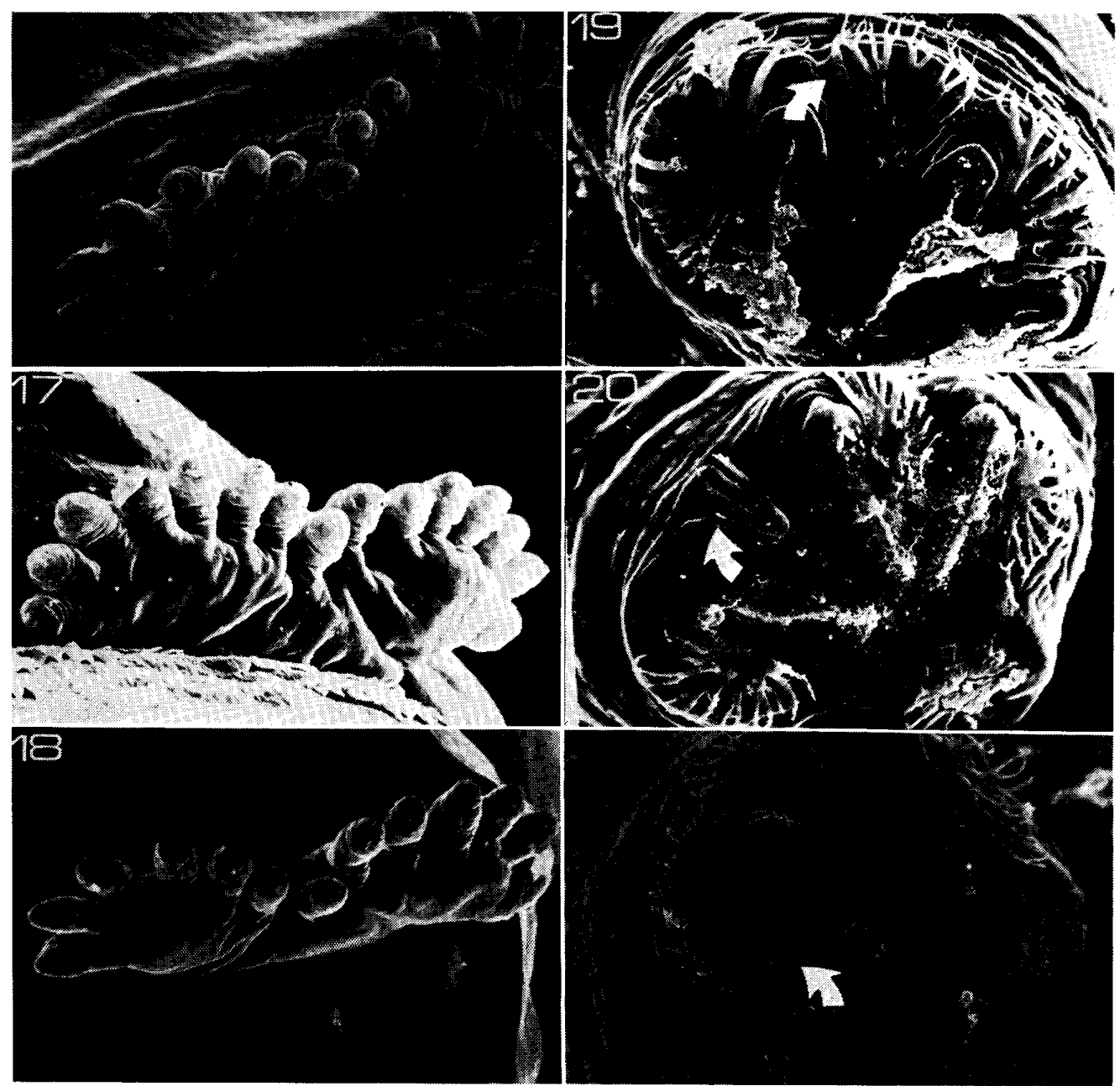

Figs. 16-18 Anterior spiracle

Fig. 16 S. scybalaria $(\times 250)$ Fig. 17 S. stercoraria $(\times 300)$ Fig. 18 S. suilla $(\times 300)$

Figs. 19-21 Posterior spiracle (arrow shows the interspiraclar process existing between middle and lower slits)

Fig. 19 S. scybalaria $(\times 200)$ Fig. 20 S. stercoraria $(\times 200)$ Fig. 21 S. suilla $(\times 300)$ 


\section{Scatophaga suilla (Fabricius, 1974)}

(Figs. 3, 6, 9, 12, 15, 18, 21)

Japanese name: Nise Kibane Fun-bae

Musca suilla Fabricius 1794, Ent. Syst., Vol.

4, p. 343

Scatomyza suilla Fallén 1819, Dipt. Suec.

Scatomyz., p. 3

Scatophaga suilla Becker 1894, Berlin. Entom. Z., Bd. 39, S. 167

Scopeuma suillum Coquillett 1900, Proc.

Wash. Acad. Sci. Vol. 2, p. 454

Body: length about $7-8 \mathrm{~mm}$, cylindrical and tapering anteriorly and truncated posteriorly, creamy white; 2 nd to 12 th segments with spine-bands; 5 th to 10 th segments with ventral spines; the last segment with 7 pairs of tubercles, a pair of mesalanal tubercles and a mesal tubercle, a pair of inner dorsal elevations evident.

Anterior spiracles: with about 13 branches.

Posterior spiracles: elliptic shaped and brownish ; button present ; interspiraclar process existing between middle and lower slits rakeform and the others dendriform.

Cephalopharyngeal sclerites: mouth hook horn shaped; accessory sclerite absent; dental sclerite triangular shaped.

Material examined: 12 examples, Nopporo, Hokkaido, X 8, 1977.

Bionomics: The adults are abundantly found on dung at a shady place similar to the place where $S$. scybalaria is found, but some are also seen on dung at sunny places.

The larvae are mainly found in dung on such shady places.

\section{ACKNOWLEDGEMENTS}

The author wishes to express his sincere thanks to Dr. Y. Sakamoto, Professor of The Junior College of Dairying and Dr. Y. Nishijima, Professor of the Obihiro University for their kindly advice and reading the manuscript. Thanks are also due to Dr. S. Shinonaga, the Tokyo Medical and Dental University for his kindness and valuable suggestions.

\section{REFERENCES}

Cotterell, G. S. (1920): The life-history and habits of the yellow dung-fly (Scatophaga stercoraria), a possible blow-fly check. Proc. Zool. Soc. London, 1920 : 629-647.

Fukuhara, N. and H. Kurahashi (1966a): Some cordylurid flies from Japan. (1). Kontyu, 34: 247 (in Japanese).

Fukuhara, N. and H. Kurahashi (1966b): Some cordylurid flies from Japan. (2). Kontyu, 34 : 288 (in Japanese).

Schumann, H. (1959/60) : Zur Biologie und Morphologie der Larven von Scopeuma stercoraria L. (Cordyluridae). Wissenschaftliche Zeitschrift der Ernst-Moritz-Arndt-Universität Greifswald. Mathematisch-naturwissenschaftliche Reihe, 3/4 : 209-215.

$$
\begin{gathered}
\text { 摘 要 } \\
\text { 北海道産ヒメフンバエ属 } 3 \text { 種（双翅目： } \\
\text { フンバェ科）の終齢幼虫の形態 }
\end{gathered}
$$

ヒメフンバェ属の沏蜘態についての詳細な記裁は, Cotterell (1920), Schumann (1959/60) など数例を数え るにすぎない。

本報は，キバネフンバエ，ヒメフンバエ，㧠びニセ キバネフンバエの終齢幼虫の一般形態および電子顕微鏡 的形態を記載した。

ヒメフンバエ属の終齢幼虫注，各体節の棘の配列，腹 部第 12 節の病状突起, 後方気門などの特徵により, 種 の同定が可能である. 